\title{
Influence of Flour Substitution and Sugar Replacement on the Physical, Proximate and Sensory Characteristics of Bread from Whole Wheat, Acha and Pigeon Pea Flour
}

\author{
G. E. Liasu-Oni and S. O. Buraimoh \\ Department of Food Science and Technology, School of Agriculture and Agricultural Technology, \\ Federal University of Technology Akure, Ondo State, Nigeria
}

\section{Abstract}

Whole wheat was cleaned and milled into flour (WWF), acha was sorted, washed and milled into acha flour (AF), pigeon pea was soaked, dehulled, dried and milled into flour (PPF), date palm fruit was cleaned, deseeded, cut, dried and milled into flour (DPFS). The flours were combined in different ratios to obtain composite flours namely WAPC (100\% WWF), WAPE (90\% WWF and 10\% AF), WAPG (80\% WWF and $20 \% \mathrm{AF})$, WAPH (70\% WWF and 30\% AF), WAPJ (80\% WWF, $10 \%$ AF and 10\% PPF), WAPK (70\% WWF, 10\% AF and 10\% PPF), WAPL (70\% WWF, 15\% AF and 15\% PPF), WAPM (60\% WWF, 20\% AF and 20\% PPF). The flours were used to bake bread, partial and total sugar replacement was carried out at 50\% (WSDC, WSDE, WSDG, WSDH, WSDJ, WSDK, WSDL and WSDM) and 100\% (WDPC, WDPE, WDPG, WDPH, WDPJ, WDPK, WDPL and WDPM). WAPC (100\% sugar) was used as control. Physical, nutritional and consumer acceptability evaluation were carried out on the formulated bread samples using standard methods. The physical properties of the formulated bread from WWF and AF were comparable to WAPC in terms of the weight and volume. Loaf height, volume and specific volume of WAPC were higher $\left(6.63 \mathrm{~cm}, 1111.67 \mathrm{~cm}^{3}\right.$ and $1.82 \mathrm{~cm}^{3} / \mathrm{g}$ respectively) than breads with $50 \%$ and $100 \%$ sugar substitution. However, the protein content of wheat-acha-pigeon pea composite bread increased significantly from $10.83 \%$ to $14.10 \%$ WDPH, WSDH were not significantly different from the WAPC in terms of its fibre, ash and fat content. The sensory characteristics of the formulated

\section{Received: September 3, 2019; Accepted: October 19, 2019}

Keywords and phrases: physical, sensory, proximate, acha, wheat, pigeon pea flour.

Copyright (C) 2019 G. E. Liasu-Oni and S. O. Buraimoh. This is an open access article distributed under the Creative Commons Attribution License, which permits unrestricted use, distribution, and reproduction in any medium, provided the original work is properly cited. 
breads compared favourably with WAPC. Thus, substitution of WWF with AF and PPF may serve as potential raw material for bread production thereby reducing overdependence on wheat, increasing the utilization and cultivation of our local cereal (acha) and increasing nutrient composition of bread. Also, sugar replacement with date palm may increase the utilization of date palm and improve the nutritional value of the breads.

\section{Introduction}

Bread is a common staple food widely consumed by people all over the world. Wheat flour is the major ingredient, likewise, it is a carbohydrate rich food with little supply of other nutrient needed by the body, hence, a need for improvement of its nutritive value achievable using composite flour including other cereals and or legume. In many parts of the world and most especially Nigeria, increasing prosperity, urbanization, increase in population in recent years have led to an increase in the consumption of wheat-based products especially biscuits and breads [1].

The flours used to produce many bakery products are bleached (or refined flours), people are discouraged from consuming them or advised to reduce the intake of foods prepared from these flours, also, some researchers refer to it as 'slow poison' or 'glue of the gut' owing to their associated adverse health effect on long time consumption, bleaching of flour leads to loss of minerals and vitamins and causes the production of alloxan that is used to induce diabetes in rats [2]. However, recent epidemiological studies have shown that the consumption of whole wheat (grains and flour) sometimes called graham flour and grain-based products is associated with reduced risk of oxidative stress related to chronic diseases and age related disorders, such as cardiovascular diseases attributed to the presence of antioxidants such as vitamin $\mathrm{C}$, vitamin $\mathrm{E}$ (tocopherols and tocotrienols) and Carotenoids [3].

Nigeria is becoming more dependent on wheat as most of its foods are made from wheat, a foreign cereal [4]. However, the production of wheat in Nigeria is very low and far below industrial needs because the Nigeria climate is not an optimum condition for its successful cultivation in large quantities [5]. Consequently, wheat is imported to Nigeria thus increasing the costs of baked products such as biscuit and bread [6]. The inability of the country to meet this demand calls for the research into alternative local sources of flour for baking. There is therefore a need to utilize composite flour in products as vehicle for essential nutrients from underutilized cereals, which could be 
complemented with legumes to formulate nutrient-dense common staple foods such as bread [7]. Effort has been made to improve the nutritional value of indigenous plant sources. Previous researches have focussed on either influence of flour substitution or sugar substitution in bread. However, there is no existing report considering the synergistic effect of both flour and sugar substitution on quality of whole wheat based bread. Hence, this study seeks to evaluate the influence of flour substitution and sugar replacement on bread properties.

\section{Materials and Methods}

Wheat grains (Triticum aestivum), pigeon pea (Cajanus cajan), date palm fruit (Phoenix dactylifera) was purchased from Oba market, Akure, Ondo state, Nigeria. Acha (Digitaria exilis) was purchased from central market, Minna, Niger state. Other baking ingredients such as margarine, salt, milk, sugar, ascorbic acid, yeast were purchased from Oba market, Akure, Ondo state. The bread was produced according to the local method of bread production. All chemicals used were of analytical grade.

\section{Determination of physical properties}

Physical analyses of the bread samples were done according to [8].

\section{Determination of proximate analyses}

The proximate analyses of the bread samples were done as described by [9].

\section{Determination of sensory properties}

Bread loaves were evaluated for taste, softness, aroma, appearance, as well as overall acceptability using a 27-member semi-trained panel, made up of students of the Federal University of Technology, Akure.

\section{Statistical Analysis}

All Analyses were carried out in triplicates. The results obtained were subjected to analysis of variance (ANOVA) using the Statistical Package for Social Sciences (SPSS) version 17.0.

\section{Results and Discussion}

The physical characteristics (weight, height, volume and specific volume) of bread 
Table 1. Physical characteristics of bread from blends of whole wheat and acha flours.

\begin{tabular}{ccccc}
\hline Sample & Height $(\mathbf{c m})$ & Weight $(\mathbf{g})$ & Volume $\left(\mathbf{c m}^{\mathbf{3}}\right)$ & $\begin{array}{c}\text { Specific Volume } \\
\left(\mathbf{c m}^{\mathbf{3}} / \mathbf{g}\right)\end{array}$ \\
\hline WDPC & $5.17 \pm 0.88^{\mathrm{c}}$ & $579.50 \pm 0.45^{\mathrm{b}}$ & $1045.00 \pm 0.29^{\mathrm{a}}$ & $1.82 \pm 0.15^{\mathrm{a}}$ \\
WSDC & $5.63 \pm 0.88^{\mathrm{b}}$ & $656.50 \pm 0.38^{\mathrm{a}}$ & $1115.00 \pm 0.29^{\mathrm{a}}$ & $1.70 \pm 0.01^{\mathrm{ab}}$ \\
WDPE & $5.30 \pm 0.12^{\mathrm{bc}}$ & $654.50 \pm 1.44^{\mathrm{a}}$ & $851.67 \pm 0.33^{\mathrm{a}}$ & $1.81 \pm 0.01^{\mathrm{a}}$ \\
WSDE & $5.47 \pm 0.88^{\mathrm{bc}}$ & $660.50 \pm 0.60^{\mathrm{a}}$ & $1095.00 \pm 0.29^{\mathrm{a}}$ & $1.65 \pm 0.01^{\mathrm{bc}}$ \\
WDPG & $4.23 \pm 0.15^{\mathrm{d}}$ & $656.00 \pm 0.58^{\mathrm{a}}$ & $995.00 \pm 0.29^{\mathrm{a}}$ & $1.52 \pm 0.01^{\mathrm{c}}$ \\
WSDG & $5.27 \pm 0.15^{\mathrm{bc}}$ & $663.00 \pm 1.73^{\mathrm{a}}$ & $1060.00 \pm 0.58^{\mathrm{a}}$ & $1.60 \pm 0.01^{\mathrm{bc}}$ \\
WDPH & $5.50 \pm 0.12^{\mathrm{bc}}$ & $620.00 \pm 1.54^{\mathrm{ab}}$ & $975.00 \pm 0.29^{\mathrm{a}}$ & $1.57 \pm 0.26^{\mathrm{bc}}$ \\
WSDH & $4.53 \pm 0.20^{\mathrm{d}}$ & $654.00 \pm 0.23^{\mathrm{a}}$ & $1060.00 \pm 0.12^{\mathrm{a}}$ & $1.62 \pm 0.01^{\mathrm{bc}}$ \\
WAPC & $6.63 \pm 0.08^{\mathrm{a}}$ & $610.09 \pm 0.58^{\mathrm{c}}$ & $1111.67 \pm 0.60^{\mathrm{a}}$ & $1.82 \pm 0.01^{\mathrm{a}}$ \\
\hline
\end{tabular}

Values are mean \pm SEM of triplicate determination. Samples with different superscripts within the same column were significantly $(\mathrm{p} \leq 0.05)$ different.

WDPC: $100 \% \mathrm{WWF}+100 \% \mathrm{DS}$; WSDC: $100 \% \mathrm{WWF}+50 \% \mathrm{DS}+50 \%$ Sugar; WDPE: $90 \%$ $\mathrm{WWF}+10 \% \mathrm{AF}+100 \% \mathrm{DS}$; WSDE: $90 \% \mathrm{WWF}+10 \% \mathrm{AF}+50 \% \mathrm{DS}+50 \%$ Sugar; WDPG: $80 \% \mathrm{WWF}+20 \% \mathrm{AF}+100 \% \mathrm{DS}$; WSDG: $80 \% \mathrm{WWF}+20 \% \mathrm{AF}+50 \% \mathrm{DS}+50 \%$ Sugar; WDPH: $70 \% \mathrm{WWF}+30 \% \mathrm{AF}+100 \% \mathrm{DS}$; WSDH: $70 \% \mathrm{WWF}+30 \% \mathrm{AF}+50 \% \mathrm{DS}+50 \%$ Sugar; WAPC: $100 \% \mathrm{WWF}+100 \%$ Sugar.

$\mathrm{WWF}=$ whole wheat flour, $\mathrm{AF}=$ acha flour, $\mathrm{DS}=$ date sugar.

were found in Tables 1 and 2. In this present study, breads made from the flour blends with 50\% sugar substitution were denser (654.00-660.50g) compared to WAPC (100\% whole wheat bread) which was lighter $(610.09 \mathrm{~g})$ and the breads with $100 \%$ sugar substitution (579.50-656.00g). According to $\mathrm{Wu}$ et al. [10], bread loaf weight is determined by amount of baked dough, moisture, and carbon dioxide diffused out of the loaf during baking. However, loaf height, volume and specific volume of WAPC were higher $\left(6.63 \mathrm{~cm}, 1111.67 \mathrm{~cm}^{3}\right.$ and $1.82 \mathrm{~cm}^{3} / \mathrm{g}$ respectively) than breads with $50 \%$ and $100 \%$ sugar substitution. The lower values observed in bread with sugar replacement may be attributable to reduced yeast food (sugar) available for fermentation. The decrease in loaf height may be a result of the decrease in the amount of readily available fermentable sugar limiting the extent of dough rising. Badifu et al. [11] reported that 
dough height depends to some extent on the volume of gas $\left(\mathrm{CO}_{2}\right)$ production during fermentation (proofing), as well as protein matrix with its level of gluten. The result of the present study corroborates this report, as the height of bread decreased with increase in flour substitution which resulted in gluten dilution/reduction. Also, bread loaf volume may be affected by protein quality and quantity. Gluten develops when wheat flour is mixed with water and it forms a matrix that retains more gas thereby increasing loaf volume and height, as a consequence of gas retention the bread loaf is lighter in weight.

Table 2. Physical characteristics of bread from blends of whole wheat, acha and pigeon pea flours.

\begin{tabular}{ccccc}
\hline Sample & Height $(\mathbf{c m})$ & Weight $(\mathbf{g})$ & Volume $\left(\mathbf{c m}^{\mathbf{3}}\right)$ & $\begin{array}{c}\text { Specific Volume } \\
\left(\mathbf{c m}^{3} / \mathbf{g}\right)\end{array}$ \\
\hline WDPJ & $5.23 \pm 0.15^{\mathrm{cd}}$ & $658.69 \pm 0.98^{\mathrm{c}}$ & $960.00 \pm 1.15^{\mathrm{d}}$ & $1.46 \pm 0.02^{\mathrm{c}}$ \\
WSDJ & $5.33 \pm 0.12^{\mathrm{c}}$ & $738.11 \pm 0.47^{\mathrm{a}}$ & $1170.00 \pm 1.15^{\mathrm{a}}$ & $1.59 \pm 0.00^{\mathrm{b}}$ \\
WDPK & $4.97 \pm 0.09^{\mathrm{de}}$ & $646.16 \pm 0.22^{\mathrm{d}}$ & $945.00 \pm 0.87^{\mathrm{d}}$ & $1 . .46 \pm 0.02^{\mathrm{c}}$ \\
WSDK & $5.17 \pm 0.09^{\mathrm{cd}}$ & $674.25 \pm 0.72^{\mathrm{b}}$ & $1070.00 \pm 1.15^{\mathrm{c}}$ & $1.59 \pm 0.01^{\mathrm{b}}$ \\
WDPL & $5.08 \pm 0.11^{\mathrm{cd}}$ & $655.46 \pm 0.84^{\mathrm{c}}$ & $945.00 \pm 0.29^{\mathrm{d}}$ & $1.44 \pm 0.01^{\mathrm{cd}}$ \\
WSDL & $6.10 \pm 0.09^{\mathrm{b}}$ & $674.38 \pm 0.25^{\mathrm{b}}$ & $960.00 \pm 1.15^{\mathrm{d}}$ & $1.42 \pm 0.03^{\mathrm{cd}}$ \\
WDPM & $4.17 \pm 0.12^{\mathrm{f}}$ & $650.08 \pm 0.04^{\mathrm{cd}}$ & $710.00 \pm 0.58^{\mathrm{f}}$ & $1.09 \pm 0.01^{\mathrm{e}}$ \\
WSDM & $4.67 \pm 0.07^{\mathrm{e}}$ & $650.15 \pm 0.08^{\mathrm{cd}}$ & $910.00 \pm 0.58^{\mathrm{e}}$ & $1.40 \pm 0.01^{\mathrm{d}}$ \\
WAPC & $6.63 \pm 0.08^{\mathrm{a}}$ & $610.09 \pm 0.58^{\mathrm{e}}$ & $1111.67 \pm 0.60^{\mathrm{b}}$ & $1.82 \pm 0.01^{\mathrm{a}}$ \\
\hline
\end{tabular}

Values are mean \pm SEM of triplicate determination. Samples with different superscripts within the same column were significantly $(\mathrm{p} \leq 0.05)$ different.

WDPJ: $80 \% \mathrm{WWF}+10 \% \mathrm{AF}+10 \% \mathrm{PPF}+100 \% \mathrm{DS}$; WSDJ: $80 \% \mathrm{WWF}+10 \% \mathrm{AF}+10 \% \mathrm{PPF}$ $+50 \%$ DS + 50\% Sugar; WDPK: $70 \% \mathrm{WWF}+20 \% \mathrm{AF}+10 \% \mathrm{PPF}+100 \%$ DS; WSDK: $70 \%$ $\mathrm{WWF}+20 \% \mathrm{AF}+10 \% \mathrm{PPF}+50 \% \mathrm{DS}+50 \%$ Sugar; $\mathrm{WDPL}: 70 \% \mathrm{WWF}+15 \% \mathrm{AF}+15 \% \mathrm{PPF}$ $+100 \%$ DS; WSDL: $70 \% \mathrm{WWF}+15 \% \mathrm{AF}+15 \% \mathrm{PPF}+50 \% \mathrm{DS}+50 \%$ Sugar; WDPM: $60 \%$ $\mathrm{WWF}+20 \% \mathrm{AF}+20 \% \mathrm{PPF}+100 \% \mathrm{DS} ; \mathrm{WSDM}: 60 \% \mathrm{WWF}+20 \% \mathrm{AF}+20 \% \mathrm{PPF}+50 \% \mathrm{DS}+$ 50\% Sugar; WAPC: $100 \%$ WWF + 100\% Sugar

$\mathrm{WWF}=$ whole wheat flour, $\mathrm{AF}=$ acha flour, $\mathrm{PPF}=$ pigeon pea flour, $\mathrm{DS}=$ date sugar. 
However, addition of acha and pigeon pea flours to whole wheat flour lowered the amount of gluten in the blends, causing poor gas retention and thus reduced loaf volume and height of the blended flour breads. The relatively large particles of pigeon pea flour have been implicated in previous report to play a significant role in reducing loaf volume by puncturing gas cells as dough expands. The results are in agreement with findings by Eggleston et al. [12] who reported a decrease in volume and specific volume of baked bread samples as wheat flour was substituted with cassava flour and starch at increasing levels.

Specific volume is the volume per unit weight of loaf, it has been generally adopted in literature as a more reliable measure of loaf size [13]. Low specific volume (1.09 to $1.82 \mathrm{~cm}^{3} / \mathrm{g}$ ) was observed for bread which suggests that the decrease in volume of loaves was not proportional to increase in weight, more so, low specific loaf volume observed could be a result of minimal hydration capacity of the flour blend. Specific volume of bread with $100 \%$ sugar substitution (WDPJ, WDPK, WDPL, and WDPM) was lower than bread with $50 \%$ substitution as well as control (100\% sugar). The least specific volume $\left(2.93 \mathrm{~cm}^{3} / \mathrm{g}\right)$ for white wheat bread baked with $100 \%$ date palm. Furthermore, specific volume of bread containing pigeon pea also reduced with increase in substitution level from $1.82 \mathrm{~cm}^{3} / \mathrm{g}$ in $100 \%$ whole wheat bread to $1.46 \mathrm{~cm}^{3} / \mathrm{g}$ for $10 \%$ pigeon pea inclusion and $1.09 \mathrm{~cm}^{3} / \mathrm{g}$ for $20 \%$ pigeon pea flour.

The result for the proximate composition was found in Table 3. Substitution with acha flour (above 10\%) resulted in increased protein content, the protein content of the breads with $50 \%$ sugar substitution increased significantly from $9.02 \%$ to $12.13 \%$ with increase in acha flour substitution than that of control (11.01\%), this may be due to high protein content in acha flour than wheat flour. More so, carbohydrate content of whole wheat bread was significantly higher $(63.91 \%)$ than bread with acha substitution (36.92 to $44.07 \%$ ). A progressive decline was observed in fat content of the bread, this occurred with increase in acha substitution from 10 to $30 \%$ (13.91 to $7.13 \%$ ), however, bread with $100 \%$ date palm had higher fat content that $50 \%$ date palm bread. This suggests that substitution with acha flour reduced the oil absorption capacity while inclusion of date palm may have increased this property. Similarly, bread from this blend with $100 \%$ sugar substitution (13.83, 3.12 and $3.15 \%$ respectively) resulted in higher values protein, ash and crude fibre contents than 50\% sugar substitution $(9.81,3.16$, and $1.62 \%$ respectively). Thus, date sugar contributed positively to the chemical composition of the 
bread. However, the protein content of wheat-acha-pigeon pea composite bread increased significantly from $10.83 \%$ to $14.10 \%$ (Table 4 ). This may be due to the incorporation of pigeon pea flour and date sugar contributing to its protein content. More so, results showed that protein content of bread increased with increase in substitution with pigeon pea flour. Bread from composite flours (wheat-acha-pigeon pea) showed higher fat content (14.06 to $26.06 \%$ ) than whole wheat flour (8.44\%).

Table 3. Proximate composition of wheat-acha composite bread as affected by sugar substitution with date palm.

\section{Composition (\%)}

\begin{tabular}{|c|c|c|c|c|c|c|}
\hline Sample & Protein & Ash & Fibre & Fat & Moisture & Carbohydrate \\
\hline WDPC & $12.42 \pm 0.01^{\mathrm{bc}}$ & $3.85 \pm 0.00^{\mathrm{a}}$ & $2.55 \pm 0.60^{b}$ & $12.75 \pm 0.57^{\mathrm{ab}}$ & $31.71 \pm 0.21^{\mathrm{cd}}$ & $36.72 \pm 1.18^{\mathrm{d}}$ \\
\hline WSDC & $9.02 \pm 0.52^{\mathrm{e}}$ & $2.18 \pm 0.52^{\mathrm{d}}$ & $2.55 \pm 0.60^{\mathrm{b}}$ & $11.97 \pm 0.86^{\mathrm{b}}$ & $36.65 \pm 0.22^{\mathrm{a}}$ & $37.63 \pm 1.69^{\mathrm{cd}}$ \\
\hline WDPE & $9.32 \pm 0.05^{\mathrm{e}}$ & $3.04 \pm 0.14^{\mathrm{b}}$ & $4.53 \pm 0.58^{\mathrm{a}}$ & $13.91 \pm 0.32^{\mathrm{a}}$ & $32.28 \pm 0.20^{\mathrm{cd}}$ & $36.92 \pm 0.65^{\mathrm{d}}$ \\
\hline WSDE & $11.40 \pm 0.32^{\mathrm{d}}$ & $2.17 \pm 0.14^{\mathrm{d}}$ & $2.35 \pm 0.60^{\mathrm{b}}$ & $11.55 \pm 0.87^{\mathrm{b}}$ & $31.56 \pm 0.14^{\mathrm{d}}$ & $40.80 \pm 0.70^{\mathrm{bc}}$ \\
\hline WDPG & $13.83 \pm 0.01^{\mathrm{a}}$ & $1.47 \pm 0.28^{\mathrm{e}}$ & $1.89 \pm 0.35^{\mathrm{b}}$ & $8.73 \pm 0.52^{\mathrm{c}}$ & $34.83 \pm 0.15^{\mathrm{b}}$ & $39.25 \pm 1.15^{\mathrm{cd}}$ \\
\hline WSDG & $10.84 \pm 0.20^{\mathrm{d}}$ & $2.40 \pm 0.28^{\mathrm{ed}}$ & $1.47 \pm 0.37^{\mathrm{b}}$ & $7.13 \pm 0.34^{\mathrm{c}}$ & $34.09 \pm 0.23^{\mathrm{b}}$ & $44 . .07 \pm 0.29^{b}$ \\
\hline WDPH & $12.75 \pm 0.02^{\mathrm{b}}$ & $1.43 \pm 0.27^{\mathrm{e}}$ & $2.03 \pm 0.39^{\mathrm{b}}$ & $8.33 \pm 0.37^{\mathrm{c}}$ & $31.46 \pm 0.11^{\mathrm{d}}$ & $44.00 \pm 0.63^{\mathrm{b}}$ \\
\hline WSDH & $12.13 \pm 0.58^{b c}$ & $2.93 \pm 0.01^{\mathrm{bc}}$ & $1.47 \pm 0.37^{\mathrm{b}}$ & $8.5 \pm 0.65^{\mathrm{c}}$ & $32.59 \pm 0.72^{\mathrm{c}}$ & $43.06 \pm 1.02^{\mathrm{b}}$ \\
\hline WAPC & $11.01 \pm 0.58^{\mathrm{d}}$ & $2.79 \pm 0.01^{\mathrm{bc}}$ & $3.08 \pm 0.35^{\mathrm{b}}$ & $8.44 \pm 0.17^{\mathrm{c}}$ & $10.77 \pm 0.40^{\mathrm{e}}$ & $63.91 \pm 1.34^{\mathrm{a}}$ \\
\hline
\end{tabular}

Values are mean \pm SEM of triplicate determination. Samples with different superscripts within the same column were significantly $(\mathrm{p} \leq 0.05)$ different.

WDPC: $100 \% \mathrm{WWF}+100 \% \mathrm{DS}$; WSDC: $100 \% \mathrm{WWF}+50 \% \mathrm{DS}+50 \%$ Sugar; WDPE: $90 \%$ $\mathrm{WWF}+10 \% \mathrm{AF}+100 \% \mathrm{DS}$; WSDE: $90 \% \mathrm{WWF}+10 \% \mathrm{AF}+50 \% \mathrm{DS}+50 \%$ Sugar; WDPG: $80 \% \mathrm{WWF}+20 \% \mathrm{AF}+100 \% \mathrm{DS}$; WSDG: $80 \% \mathrm{WWF}+20 \% \mathrm{AF}+50 \% \mathrm{DS}+50 \%$ Sugar; WDPH: $70 \% \mathrm{WWF}+30 \% \mathrm{AF}+100 \% \mathrm{DS}$; WSDH: $70 \% \mathrm{WWF}+30 \% \mathrm{AF}+50 \% \mathrm{DS}+50 \%$ Sugar; WAPC: $100 \% \mathrm{WWF}+100 \%$ Sugar.

$\mathrm{WWF}=$ whole wheat flour, $\mathrm{AF}=$ acha flour, $\mathrm{DS}=$ date sugar.

This may be attributed to increased oil absorption capacity in the composite flours. The presence of high fat content in the bread relates to high calorific value and serves as 
a lubricating agent that improves the sensorial quality (softness and aroma). Moreover, fat is a rich source of energy and essential as carrier of fat-soluble vitamins (A, D, E and $\mathrm{K})$. However, fat $\leq 25 \%$ fat content has been recommended for baked goods to prevent rancidity in such food products [14].

Table 4. Proximate composition of wheat-acha-pigeon pea composite bread as affected by sugar substitution with date palm.

Composition (\%)

\begin{tabular}{|c|c|c|c|c|c|c|}
\hline Sample & Protein & Ash & Fibre & Fat & Moisture & Carbohydrate \\
\hline WDPJ & $10.83 \pm 0.00^{\mathrm{c}}$ & $4.14 \pm 0.15^{\mathrm{a}}$ & $1.60 \pm 0.42^{\mathrm{bc}}$ & $17.51 \pm 0.14^{\mathrm{b}}$ & $32.28 \pm 0.29^{c}$ & $33.65 \pm 0.37^{\mathrm{c}}$ \\
\hline WSDJ & $9.22 \pm 0.590^{\mathrm{d}}$ & $2.22 \pm 015^{\mathrm{d}}$ & $1.48 \pm 0.36^{\mathrm{c}}$ & $18.24 \pm 0.30^{\mathrm{b}}$ & $29.56 \pm 0.22^{\mathrm{f}}$ & $39.28 \pm 0.72^{\mathrm{b}}$ \\
\hline WDPK & $13.83 \pm 0.01^{\mathrm{a}}$ & $3.12 \pm 0.15^{\mathrm{b}}$ & $3.15 \pm 0.55^{\mathrm{a}}$ & $14.38 \pm 0.86^{\mathrm{c}}$ & $35.21 \pm 0.01^{\mathrm{a}}$ & $30.91 \pm 0.66^{\mathrm{d}}$ \\
\hline WSDK & $9.81 \pm 0.36^{\mathrm{d}}$ & $3.16 \pm 0.14^{\mathrm{b}}$ & $1.62 \pm 0.40^{\mathrm{bc}}$ & $26.06 \pm 0.29^{\mathrm{a}}$ & $30.12 \pm 0.18^{\text {ef }}$ & $29.24 \pm 0.85^{\mathrm{d}}$ \\
\hline WDPL & $12.04 \pm 0.02^{\mathrm{b}}$ & $2.42 \pm 0.28^{\mathrm{cd}}$ & $3.14 \pm 0.44^{\mathrm{a}}$ & $14.06 \pm 0.33^{\mathrm{c}}$ & $31.02 \pm 0.20^{\mathrm{d}}$ & $30.32 \pm 1.04^{\mathrm{d}}$ \\
\hline WSDL & $11.48 \pm 0.06^{\mathrm{bc}}$ & $2.93 \pm 0.01^{\mathrm{b}}$ & $1.50 \pm 0.05^{\mathrm{c}}$ & $14.33 \pm 0.30^{\mathrm{c}}$ & $31.06 \pm 0.16^{\mathrm{d}}$ & $38.71 \pm 0.34^{\mathrm{b}}$ \\
\hline WDPM & $14.10 \pm 0.06^{\mathrm{a}}$ & $2.85 \pm 0.01^{\mathrm{bc}}$ & $2.65 \pm 0.48^{\mathrm{abc}}$ & $14.06 \pm 0.33^{\mathrm{c}}$ & $33.60 \pm 0.10^{\mathrm{b}}$ & $29.75 \pm 0.34^{\mathrm{a}}$ \\
\hline WSDM & $13.58 \pm 0.05^{\mathrm{a}}$ & $3.13 \pm 0.12^{b}$ & $2.84 \pm 0.17^{\mathrm{ab}}$ & $25.56 \pm 0.32^{\mathrm{a}}$ & $30.72 \pm 0.27^{\mathrm{e}}$ & $24.17 \pm 0.50^{\mathrm{e}}$ \\
\hline WAPC & $11.01 \pm 0.58^{\mathrm{c}}$ & $2.79 \pm 0.01^{c}$ & $3.08 \pm 0.35^{\mathrm{a}}$ & $8.44 \pm 0.17^{\mathrm{d}}$ & $10.77 \pm 0.40^{\mathrm{g}}$ & $63.91 \pm 1.34^{\mathrm{a}}$ \\
\hline
\end{tabular}

Values are mean \pm SEM of triplicate determination. Samples with different superscripts within the same column were significantly $(\mathrm{p} \leq 0.05)$ different.

WDPJ: $80 \% \mathrm{WWF}+10 \% \mathrm{AF}+10 \% \mathrm{PPF}+100 \% \mathrm{DS}$; WSDJ: $80 \% \mathrm{WWF}+10 \% \mathrm{AF}+10 \% \mathrm{PPF}$ + 50\% DS + 50\% Sugar; WDPK: $70 \% \mathrm{WWF}+20 \% \mathrm{AF}+10 \% \mathrm{PPF}+100 \% \mathrm{DS} ; \mathrm{WSDK}: 70 \%$ $\mathrm{WWF}+20 \% \mathrm{AF}+10 \% \mathrm{PPF}+50 \% \mathrm{DS}+50 \%$ Sugar; $\mathrm{WDPL}: 70 \% \mathrm{WWF}+15 \% \mathrm{AF}+15 \% \mathrm{PPF}$ $+100 \%$ DS; WSDL: $70 \% \mathrm{WWF}+15 \% \mathrm{AF}+15 \% \mathrm{PPF}+50 \% \mathrm{DS}+50 \%$ Sugar; WDPM: $60 \%$ $\mathrm{WWF}+20 \% \mathrm{AF}+20 \% \mathrm{PPF}+100 \% \mathrm{DS} ; \mathrm{WSDM}: 60 \% \mathrm{WWF}+20 \% \mathrm{AF}+20 \% \mathrm{PPF}+50 \% \mathrm{DS}+$ $50 \%$ Sugar; WAPC: $100 \%$ WWF + 100\% Sugar

$\mathrm{WWF}=$ whole wheat flour, $\mathrm{AF}=$ acha flour, $\mathrm{PPF}=$ pigeon pea flour, $\mathrm{DS}=$ date sugar.

The mean sensory scores of bread loaves are shown in Tables 5 and 6 . The appearance, softness, aroma, taste and overall acceptability of the control bread were significantly different from the breads from breads from composite flours. More so, there was no significant difference in the softness and taste of whole wheat-acha bread (with 
up to $20 \%$ acha substitution). Overall acceptability of breads with $50 \%$ sugar substitution compare favourably with control. The non-difference in preference for aroma of bread may be expected if the sweetness of the same mass of date sugar and granulated is equivalent [15] unless contributions of phytochemical found in date meal, as impure substance, could come into play. The scores for the breads containing $100 \%$ whole wheat and $100 \%$ sugar were the highest among the evaluated breads. However, with respect to overall acceptability, the bread was rated above 5.6 on a nine point hedonic scale thus, they were fairly acceptable to consumers. Although, wheat-acha bread showed better acceptability than wheat-acha-pigeon pea bread.

Table 5. Sensory characteristics of bread from blends of whole wheat and acha flours.

\begin{tabular}{cccccc}
\hline Sample & Appearance & Aroma & Softness & Taste & $\begin{array}{c}\text { Overall } \\
\text { Acceptability }\end{array}$ \\
\hline WDPC & $7.07 \pm 0.19^{\mathrm{b}}$ & $6.69 \pm 0.24^{\mathrm{bc}}$ & $6.41 \pm 0.25^{\mathrm{b}}$ & $6.00 \pm 0.31^{\mathrm{b}}$ & $6.83 \pm 0.18^{\mathrm{bc}}$ \\
WSDC & $7.21 \pm 0.24^{\mathrm{b}}$ & $6.76 \pm 0.30^{\mathrm{bc}}$ & $6.52 \pm 0.03^{\mathrm{b}}$ & $6.76 \pm 0.35^{\mathrm{b}}$ & $7.14 \pm 0.25^{\mathrm{b}}$ \\
WDPE & $7.14 \pm 0.20^{\mathrm{b}}$ & $6.69 \pm 0.25^{\mathrm{bc}}$ & $6.45 \pm 0.27^{\mathrm{b}}$ & $6.69 \pm 0.33^{\mathrm{b}}$ & $7.01 \pm 0.24^{\mathrm{bc}}$ \\
WSDE & $7.03 \pm 0.21^{\mathrm{b}}$ & $6.93 \pm 0.22^{\mathrm{ab}}$ & $6.55 \pm 0.30^{\mathrm{b}}$ & $6.97 \pm 0.29^{\mathrm{b}}$ & $6.97 \pm 0.24^{\mathrm{bc}}$ \\
WDPG & $6.93 \pm 0.18^{\mathrm{b}}$ & $6.62 \pm 0.31^{\mathrm{bc}}$ & $6.45 \pm 0.28^{\mathrm{b}}$ & $6.69 \pm 0.29^{\mathrm{b}}$ & $7.10 \pm 0.26^{\mathrm{bc}}$ \\
WSDG & $6.83 \pm 0.18^{\mathrm{b}}$ & $6.44 \pm 0.25^{\mathrm{bc}}$ & $6.62 \pm 0.18^{\mathrm{b}}$ & $6.41 \pm 0.28^{\mathrm{b}}$ & $6.65 \pm 0.24^{\mathrm{bc}}$ \\
WDPH & $6.66 \pm 0.19^{\mathrm{b}}$ & $5.93 \pm 0.31^{\mathrm{c}}$ & $6.10 \pm 0.28^{\mathrm{b}}$ & $6.21 \pm 0.37^{\mathrm{b}}$ & $6.38 \pm 0.23^{\mathrm{c}}$ \\
WSDH & $6.83 \pm 0.22^{\mathrm{b}}$ & $6.21 \pm 0.28^{\mathrm{bc}}$ & $6.52 \pm 0.30^{\mathrm{b}}$ & $6.38 \pm 0.31^{\mathrm{b}}$ & $6.72 \pm 0.28^{\mathrm{bc}}$ \\
WAPC & $7.83 \pm 0.11^{\mathrm{a}}$ & $7.52 \pm 0.15^{\mathrm{a}}$ & $7.62 \pm 0.14^{\mathrm{a}}$ & $7.97 \pm 0.15^{\mathrm{a}}$ & $7.90 \pm 0.13^{\mathrm{a}}$ \\
\hline
\end{tabular}

Values are mean \pm SEM of triplicate determination. Samples with different superscripts within the same column were significantly $(\mathrm{p} \leq 0.05)$ different.

WDPC: $100 \% \mathrm{WWF}+100 \% \mathrm{DS}$; WSDC: $100 \% \mathrm{WWF}+50 \% \mathrm{DS}+50 \%$ Sugar; WDPE: $90 \%$ $\mathrm{WWF}+10 \% \mathrm{AF}+100 \% \mathrm{DS}$; WSDE: $90 \% \mathrm{WWF}+10 \% \mathrm{AF}+50 \% \mathrm{DS}+50 \%$ Sugar; $\mathrm{WDPG}:$ $80 \% \mathrm{WWF}+20 \% \mathrm{AF}+100 \% \mathrm{DS} ; \mathrm{WSDG}: 80 \% \mathrm{WWF}+20 \% \mathrm{AF}+50 \% \mathrm{DS}+50 \%$ Sugar; WDPH: $70 \% \mathrm{WWF}+30 \% \mathrm{AF}+100 \% \mathrm{DS}$; WSDH: $70 \% \mathrm{WWF}+30 \% \mathrm{AF}+50 \% \mathrm{DS}+50 \%$ Sugar; WAPC: $100 \% \mathrm{WWF}+100 \%$ Sugar.

$\mathrm{WWF}=$ whole wheat flour, $\mathrm{AF}=$ acha flour, $\mathrm{DS}=$ date sugar. 
Table 6. Sensory characteristics of bread from blends of whole wheat, acha and pigeon pea flours.

\begin{tabular}{|c|c|c|c|c|c|}
\hline Sample & Appearance & Aroma & Softness & Taste & $\begin{array}{c}\text { Overall } \\
\text { Acceptability }\end{array}$ \\
\hline WDPJ & $6.38 \pm 0.23^{b}$ & $6.10 \pm 0.40^{\mathrm{b}}$ & $5.66 \pm 0.32^{b c}$ & $5.72 \pm 0.34^{b c}$ & $6.17 \pm 0.33^{b}$ \\
\hline WSDJ & $6.38 \pm 0.31^{b}$ & $6.31 \pm 0.32^{b}$ & $6.34 \pm 0.32^{b}$ & $6.31 \pm 0.42^{b}$ & $6.55 \pm 0.36^{b}$ \\
\hline WDPK & $6.24 \pm 0.30^{b}$ & $5.52 \pm 0.30^{\mathrm{b}}$ & $5.31 \pm 0.30^{c}$ & $5.34 \pm 0.29^{b c}$ & $5.86 \pm 0.28^{b}$ \\
\hline WSDK & $6.62 \pm 0.26^{b}$ & $5.93 \pm 0.28^{b}$ & $6.17 \pm 0.26^{\mathrm{bc}}$ & $5.62 \pm 0.33^{b c}$ & $5.97 \pm 0.33^{b}$ \\
\hline WDPL & $6.31 \pm 0.28^{\mathrm{b}}$ & $5.41 \pm 0.36^{\mathrm{b}}$ & $6.03 \pm 0.32^{\mathrm{bc}}$ & $4.86 \pm 0.35^{\mathrm{c}}$ & $5.72 \pm 0.31^{\mathrm{b}}$ \\
\hline WSDL & $6.45 \pm 0.30^{b}$ & $5.55 \pm 0.33^{b}$ & $5.97 \pm 0.39^{\mathrm{bc}}$ & $5.21 \pm 0.40^{\mathrm{bc}}$ & $5.93 \pm 0.31^{b}$ \\
\hline WDPM & $6.45 \pm 0.23^{b}$ & $5.48 \pm 0.33^{b}$ & $5.86 \pm 0.25^{b c}$ & $5.21 \pm 0.37^{b c}$ & $5.69 \pm 0.36^{\mathrm{b}}$ \\
\hline WSDM & $6.76 \pm 0.20^{b}$ & $5.69 \pm 0.38^{b}$ & $6.31 \pm 0.31^{b}$ & $5.52 \pm 0.38^{b c}$ & $6.69 \pm 0.26^{b}$ \\
\hline WAPC & $7.66 \pm 0.18^{\mathrm{a}}$ & $7.48 \pm 0.21^{\mathrm{a}}$ & $7.52 \pm 0.27^{\mathrm{a}}$ & $7.65 \pm 0.30^{\mathrm{a}}$ & $7.90 \pm 0.22^{\mathrm{a}}$ \\
\hline
\end{tabular}

Values are mean \pm SEM of triplicate determination. Samples with different superscripts within the same column were significantly $(\mathrm{p} \leq 0.05)$ different.

WDPJ: $80 \% \mathrm{WWF}+10 \% \mathrm{AF}+10 \% \mathrm{PPF}+100 \% \mathrm{DS}$; WSDJ: $80 \% \mathrm{WWF}+10 \% \mathrm{AF}+10 \% \mathrm{PPF}$ + 50\% DS + 50\% Sugar; WDPK: $70 \% \mathrm{WWF}+20 \% \mathrm{AF}+10 \% \mathrm{PPF}+100 \% \mathrm{DS}$; WSDK: $70 \%$ $\mathrm{WWF}+20 \% \mathrm{AF}+10 \% \mathrm{PPF}+50 \% \mathrm{DS}+50 \%$ Sugar; $\mathrm{WDPL}: 70 \% \mathrm{WWF}+15 \% \mathrm{AF}+15 \% \mathrm{PPF}$ $+100 \%$ DS; WSDL: $70 \% \mathrm{WWF}+15 \% \mathrm{AF}+15 \% \mathrm{PPF}+50 \% \mathrm{DS}+50 \%$ Sugar; WDPM: $60 \%$ $\mathrm{WWF}+20 \% \mathrm{AF}+20 \% \mathrm{PPF}+100 \% \mathrm{DS} ; \mathrm{WSDM}: 60 \% \mathrm{WWF}+20 \% \mathrm{AF}+20 \% \mathrm{PPF}+50 \% \mathrm{DS}+$ $50 \%$ Sugar; WAPC: $100 \%$ WWF $+100 \%$ Sugar

$\mathrm{WWF}=$ whole wheat flour, $\mathrm{AF}=$ acha flour, $\mathrm{PPF}=$ pigeon pea flour, $\mathrm{DS}=$ date sugar.

\section{Conclusion}

It can be concluded that the partial or total replacement of sugar with date palm and substitution of wheat flour with acha and pigeon pea flours did not negatively affect the weight and volume of the bread. Date fruit has potential as a suitable alternative to sugar in bread production and as sweetening agent to replace granulated sugar in bread production improved the nutritional value of bread (protein, ash, crude fibre). The overall acceptability of bread from composite flour compared favourably with control and the product was fairly accepted with an average score above 5.60. 


\section{Acknowledgments}

The authors are grateful to The Federal University of Technology Akure for her contribution to this research.

\section{References}

[1] A. A. Adebowale, M. T. Adegoke, S. A. Sanni, M. O. Adegunwa and G. O. Fetuga, Functional properties of biscuit making potential of sorghum-wheat flour composite, American Journal of Food Technology 7(6) (2012), 372-379.

https://doi.org/10.3923/ajft.2012.372.379

[2] T. Erleen, www.livingahealthylifestyle.com, 2011. Accessed 5th April, 2016.

[3] Lilei Yu, Anne-Laure Nanguet and Trust Beta, Comparison of antioxidant properties of refined and whole wheat flour and bread, Antioxidants 2 (2013), 370-383. https://doi.org/10.3390/antiox2040370

[4] J. A. Ayo, U. S. Haruna, B. Yelmi, V. A. Ayo and G. Ajayi, Effect of informers on the quality of acha bread, Nigerian Food Journal 26(1) (2008), 56-63.

[5] A. A. Olapade and O. B. Oluwole, Bread making potential of composite flour of wheatacha enriched with cowpea flour, Nigerian Food Journal 31(1) (2013), 6-12. https://doi.org/10.1016/S0189-7241(15)30050-3

[6] H. D. Mepba, L. Eboh and S. U. Nwaojigwa, Chemical composition, functional and baking properties of wheat-plantain composite flours, Afr. J. Food Agric. Nutr. Dev. 7(1) (2007), 1-22.

[7] I. E. Mbaeyi-Nwaoha, P. C. Egbo, E. C. Omah and G. I. Davidson, Production and quality assessment of gluten-free and nutrient-dense biscuits from acha, pigeon pea and sweet potato blends, International Journal of Food Nutrition Science 2(2) (2015), 129-139. https://doi.org/10.15436/2377-0619.15.030

[8] AACC Approved Methods of the AACC, 10th ed., American Association of Cereal Chemists, St. Paul., 2000.

[9] AOAC Official Methods of Analysis, 18th ed., Association of Official Analytical Chemists, Washington D.C., USA, 2005.

[10] K. L. Wu, W. C. Sung and C. H. Yang, Characteristics of dough and bread as affected by the incorporation of sweet potato paste in the formulation, Journal of Marine Science and Technology 17(1) (2009), 13-22. 
[11] G. I. O. Badifu, C. E. Chima, Y. I. Ajayi and A. F. Ogori, Influence of mango mesocarp flour supplement to micronutrient, physical and organoleptic qualities of wheat-based bread, Nigerian Food Journal 23 (2005), 59-68.

https://doi.org/10.4314/nifoj.v23i1.33600

[12] G. Eggleston, P. O. Omoaka and A. U. Arowshegbe, Flour, starch and composite breadmaking quality of various cassava clones, Journal of Sciences and Food Agriculture 62 (1993), 49-59. https://doi.org/10.1002/jsfa.2740620107

[13] T. A. Shittu, A. O. Raji and L. O. Sanni, Bread from composite cassava-wheat flour: I. Effect of baking time and temperature on some physical properties of bread loaf, Food Research International 40 (2007), 280-290.

https://doi.org/10.1016/j.foodres.2006.10.012

[14] A. I. Ihekoronye and P. O. Ngoddy, Integrated Food Science and Technology for the Tropics, London: Macmillan, 1985.

[15] F. Khan, Natural Ingredient You Can Use to Replace Sugar, Demand Media Inc., 2010. http://www.livestrong.com/ Accessed June 2012. 